\title{
Pharmacological evidence for the folk use of Nefang: antipyretic, anti-inflammatory and antinociceptive activities of its constituent plants
}

Protus Arrey Tarkang ${ }^{1,2^{*}}$, Faith A. Okalebo ${ }^{2}$, Juma D. Siminyu ${ }^{2}$, William N. Ngugi ${ }^{2}$, Amos M. Mwaura², Jackson Mugweru ${ }^{3}$, Gabriel A. Agbor ${ }^{1}$ and Anastasia N. Guantai ${ }^{2}$

\begin{abstract}
Background: Nefang is a polyherbal anti-malarial composed of Mangifera indica (MiB and MiL; bark and leaf), Psidium guajava $(\mathrm{Pg})$, Carica papaya $(\mathrm{Cp})$, Cymbopogon citratus (Cc), Citrus sinensis $(\mathrm{Cs})$ and Ocimum gratissimum $(\mathrm{Og})$ (leaves). Previous studies have demonstrated its in vitro and in vivo antiplasmodial activities, antioxidant properties and safety profile. This study aimed at evaluating the antipyretic, anti-inflammatory and antinociceptive activities of the constituent plants of Nefang which are relevant to the symptomatic treatment of malaria fever.

Methods: Antipyretic activities were determined by the D-Amphetamine induced pyrexia and Brewer's Yeast induced hyperpyrexia methods. Anti-inflammatory activities were investigated using the carrageenan-induced rat paw edema method. Antinociceptive activities were determined by mechanical nociception in the tail pressure and thermal nociception in the radiant heat tail flick and hot plate methods. Data was analysed using the one way ANOVA followed by Neuman-Keuls multiple comparison test.

Results: Best percentage inhibition of induced pyrexia (amphetamine/brewer's yeast; $p<0.05$ ) was exhibited by CC (95/97) followed by Og (85/94), MiL (90/89), MiB (88/84) and Cs (82/89). CC and Og exhibited comparable activities to paracetamol (100/95).

Anti-inflammatory studies revealed paw edema inhibition (\%) as follows ( $p<0.05)$ : Indomethacin (47), MiL (40), Cp (30), MiB (28) and Og (22), suggesting best activity by MiL.

Antinociceptive studies revealed significant $(p<0.01)$ pain inhibition (\%) as follows: Paracetamol (97), Og (113), MiL (108), Pg (84) and MiB (88). Og and Mil exhibited the best activities.

Conclusion: The results obtained suggest that the constituent plants possess biologically active compounds with antipyretic, anti-inflammatory and antinociceptive activities. These activities are essential in the symptomatic treatment of malaria fever, thereby justifying the folk use of Nefang. This would be useful in its subsequent development for clinical application.
\end{abstract}

Keywords: Medicinal plants, Nefang, Pharmacological effects, Antipyretic, Anti-inflammatory, Antinociceptive activities

\footnotetext{
* Correspondence: ptarkang@yahoo.co.uk

${ }^{1}$ Centre for Research on Medicinal Plants and Traditional Medicine, Institute of Medical Research and Medicinal Plants Studies (IMPM), P. O. Box 6163,

Yaoundé, Cameroon

2Department of Pharmacology and Pharmacognosy, School of Pharmacy,

University of Nairobi, P. O. Box 19676-00202, Nairobi, Kenya

Full list of author information is available at the end of the article
} 


\section{Background}

Overseas development assistance to low and middle income countries (LMICs) have led to substantial improvement in the number of vulnerable populations protected against malaria infection, especially in those who have access to drugs that effectively treat the disease [1]. In spite of this, Plasmodium falciparum malaria remains a major public health burden in most endemic African countries, where there is lack of access to modern healthcare facilities and disease monitoring is not well defined. The emerging resistance of the parasite to currently available drugs makes the situation even more complicated. The disease remains one of the major threats to public health and the economic development of these countries [2,3]. Most of the populations resort to the use of plant-based complementary medicine for therapy [4].

Natural compounds have provided the best anti-malarials known to date. Examples include chloroquine from Cinchona species, artemisinin from Artemisia annua and atovaquone from Tabebuia impetiginosa $[5,6]$. Their advantage for the development of drugs comes from the synergistic interactions of their components and their innate affinity for biological receptors [7]. The pharmacological justification of these principles could provide the basis for further development of plant-based traditional medicine as a reliable therapeutic tool.

Nefang is a polyherbal product composed of Mangifera indica (bark and leaf), Psidium guajava, Carica papaya, Cymbopogon citratus, Citrus sinensis and Ocimum gratissimum (leaves). It is frequently used for the treatment of malaria in the South West Region of Cameroon. Ethnopharmacological studies confirmed its formulation, folk use and a review of the biological activities of its constituent plants [8]. Use of Nefang for the treatment of malaria raises the question as to whether the therapeutic effects are as a result of the antiplasmodial activity of its constituents or to their ability to ameliorate the symptoms of malaria or a combination of both effects.

Evaluation of the in vitro and in vivo antioxidant properties of this polyherbal revealed potential free radical scavenging and antioxidant activities of some constituent plants. These activities correlated with their phenolic content and are believed to contribute to the demonstrated in vivo antioxidant activity of Nefang and play a role in curbing oxidative stress associated with malaria infection [9].

The in vitro antiplasmodial activities of this polyherbal and solvent extracts of its constituent plants has earlier been evaluated, revealing good activity and potential synergistic interactions between some of its components [10]. This synergy is believed to contribute favorably towards its antiplasmodial activity. The good antiplasmodial activity and demonstrated weak cytotoxicity of the constituent extracts suggested a high selectivity for $P$. falciparum. Preliminary phytochemical screening of its constituent plants revealed the presence of alkaloids, anthocyanins, flavonoids, phenols, saponins, tannins, triterpenes and sterols [10]. The synergy of these active and non-antiplasmodial compounds is responsible for the antiplasmodial activity of Nefang.

Our recent studies demonstrated the antimalarial efficacy of Nefang during early and established Plasmodium infection, revealing good suppression of parasitemia and chemotherapeutic activities [11]. We have also established the in vivo safety profile of Nefang.

This study aimed at providing pharmacological evidence on the folk use of Nefang by evaluating the effects of its constituent plants on induced pyrexia, inflammation and nociception in experimental rodent models.

\section{Methods}

\section{Extraction of plant material}

Fresh parts of the constituent plants of Nefang were identified and harvested from their natural habitat in Cameroon. Identification was done by a botanist, Dr. Tsabang Nole of the Institute of Medical Research and Medicinal Plants Studies (IMPM), Yaoundé, Cameroon with voucher specimen references as follows: $M$. indica (TN6225), P. guajava (TN6226), C. papaya (TN6227), C. citratus (TN6228), C. sinensis (TN6229), O. gratissimum (TN6230). Aqueous extractions were performed as earlier described [10] using pyrogen-free distilled water. Each filtrate was then concentrated in an air oven at $60{ }^{\circ} \mathrm{C}$. The extracts were weighed and stored in labeled sealed plastic containers at $4{ }^{\circ} \mathrm{C}$ until use.

\section{Experimental animals}

Swiss albino mice (20-25 g) were used for testing antinociceptive activity while wistar rats $(170-200 \mathrm{~g})$ were used for antipyretic and anti-inflammatory activities.

All experimental animals were housed under standard environmental conditions of temperature at $22-24{ }^{\circ} \mathrm{C}$ under a $12 \mathrm{~h}$ dark-light cycle, and allowed free access to drinking water and standard pellet diet.

Ethical approval for the study was obtained from Kenyatta National Hospital/University of Nairobi Ethics and Research committee, Nairobi-Kenya (KNH-ERC/A/ $324-5 / 12 / 12)$.

\section{Tests for antipyretic activity}

\section{D-Amphetamine induced pyrexia method}

The antipyretic activities of the constituent aqueous plant extracts of Nefang were determined by the DAmphetamine induced pyrexia method [12]. Wistar rats of both sexes were fasted for $24 \mathrm{~h}$. At zero hour, the basal temperature of all the animals was taken using an infrared thermometer. D-amphetamine $\left(5 \mathrm{mgkg}^{-1}\right)$ was then administered to all the animals. After 30 min, sixty four 
animals with an increase in body temperature of $0.5-1{ }^{\circ} \mathrm{C}$ were selected for the study. They were randomized into sixteen groups of four rats each. Group 1 was treated with $10 \mathrm{mLkg}^{-1}$ of the vehicle (normal saline), group 2 - the reference drug (Paracetamol, $150 \mathrm{mgkg}^{-1}$ ) and two groups for each extract were treated orally with 200 and 400 $\mathrm{mgkg}^{-1}$ bwt of each extract. Body temperatures were obtained at 60, 120, 180 and 240 min after drug administration. The percentage suppression of induced pyrexia in the extract-treated groups was compared with that of the control to evaluate the activity of each extract.

\section{Brewer's yeast-induced hyperpyrexia method}

Brewer's yeast-induced hyperpyrexia method was used to determine the antipyretic activities of the constituent plants of Nefang [13]. Wistar rats of both sexes were fasted for $24 \mathrm{~h}$ and then randomized into sixteen groups of three rats each. At zero hour, the basal temperature of each rat was taken using an infra-red thermometer. Thereafter, each animal received a subcutaneous injection of 10 $\mathrm{mLkg}^{-1}$ of aqueous yeast suspension $(20 \% \mathrm{w} / \mathrm{v})$ to elevate the body temperature. Eighteen hours post yeast injection, $10 \mathrm{mLkg}^{-1}$ of the standard drug (aspirin, $100 \mathrm{mgkg}^{-1}$ ), the vehicle (normal saline), 200 and $400 \mathrm{mgkg}^{-1}$ of each aqueous extract were administered orally to different groups of rats. Body temperature of each animal was recorded at 0 , 60, 120 and $180 \mathrm{~min}$ after drug administration and the activity of each extract evaluated.

\section{Test for anti-inflammatory activity}

In vivo anti-inflammatory activities of the constituent plants of Nefang were evaluated using the carrageenaninduced rat paw edema method [14]. Ninety-two adult wistar rats were randomly divided into twenty three groups of four each. Paw volumes were measured at zero minute using the Archimedes principle of mercury displacement in a plethysmograph. Thereafter, $10 \mathrm{mLkg}^{-1}$ of the vehicle (normal saline), the reference drug (Indomethacin, $10 \mathrm{mgkg}^{-1}$ ), and 100,200 and $400 \mathrm{mgkg}^{-1}$ bwt of each extract were administered orally to different groups of rats. Thirty minutes later, paw edema was induced in each rat by injecting $0.1 \mathrm{~mL}$ of carrageenan $(1 \%$ in normal saline) to the right hind paw. Paw volumes were measured at $60,120,180$ and $240 \mathrm{~min}$. The difference between the paw volume at zero minute and each time point was taken as a measure of edema. The percentage inhibition of paw volumes in extract-treated groups was compared with the standard drug to evaluate the activity of the extracts.

\section{Tests for antinociceptive activity}

\section{Tail pressure method}

The method described by Randall and Selitto [15] and modified by Kitchen [16] was used for the evaluation of analgesic activities of the constituent extracts. Thirty-six
Swiss albino mice were randomly divided into nine groups of four each. At zero minute, the tail of each mouse was put on the tip of an analgesy-meter and pressure gradually increased up to a maximum of 25 units. The pressure at which the mouse began to struggle was noted and recorded. Mice in group 1 (positive control) were treated by intraperitoneal injection with $0.1 \mathrm{~mL}$ of the standard drug (morphine, $5 \mathrm{mgkg}^{-1}$ ); group $2-$ phosphate buffered saline (PBS); group $3-7$ were each treated with $10 \mathrm{mLkg}^{-1}$ of $1000 \mathrm{mgkg}^{-1}$ bwt of each aqueous plant extract. After $30 \mathrm{~min}$, mechanical pain was induced on the tail of each restrained mouse in turn by the use of analgesy-meter. The force was continuously monitored by a pointer moving along a linear scale. The weight causing pain before treatment $(0 \mathrm{~min})$ and then at 30,60, 90 and $120 \mathrm{~min}$ post extract/drug treatment was recorded. Percentage pain inhibition (increase in pain threshold) produced relative to the control group was calculated for each extract-treated group and compared with the standard drug-treated group, using the following equation:

$$
\text { Pain inhibition }(\%)=\frac{\text { Ft-Fo }}{\text { Fo }} \times 100
$$

Where $\mathrm{Ft}=$ Force at which the animal tries to free its tail after drug administration.

Fo $=$ Force at which the animal tries to free its tail before drug administration.

Extracts that showed activity were then subjected to further dose-response testing.

\section{Tail flick response method}

The analgesic activity of each of the constituent plants of Nefang was determined by radiant heat tail-flick method [17]. The tail flick latency was assessed by an analgesiometer (Inco, India). Before selecting each mouse for the test, a baseline reaction was taken by placing the tip of the tail of each mouse on the radiant heat source from an analgesiometer. The strength of the current passing through the naked nichrome wire was kept constant at 5 amperes. The distance between the heat source and the mouse tails was $1.5 \mathrm{~cm}$ and the application site of the heat on the tail was maintained within $2 \mathrm{~cm}$. Each mouse in turn was held in a suitable restrainer with tail protruding out. Radiant heat from the analgesiometer was applied on a designated spot on the tail. The time interval between the onset of stimulus and withdrawal (flicking) of the tail was taken as the reaction time for each mouse. Cut-off reaction time was $10 \mathrm{sec}$ to avoid tissue injury during the process. The initial flicking time of each group was considered as the control reading. 
One hundred and ten mice that responded positively were randomly divided into twenty-two groups of five each. Group 1 (positive control) was treated with $0.1 \mathrm{~mL}$ of the standard drug (Paracetamol, $10 \mathrm{mgkg}^{-1}$ ) while the rest of the twenty-one groups were divided into three groups per aqueous extract and administered 300, 600 and $1200 \mathrm{mgkg}^{-1}$ bwt respectively of each aqueous extract by intraperitoneal injection. The tip of the tail of each mouse was then exposed to the heat source from the analgesiometer and reaction time recorded at intervals of $30 \mathrm{~min}$ till $120 \mathrm{~min}$. The percentage of pain inhibition was calculated for each extract-treated group and compared with that of the standard drug-treated group using the following equation:

$$
\text { Percentage inhibition }=\frac{(\text { Test mean })_{\mathrm{t}}-(\text { Control mean })_{\mathrm{t}}}{(\text { Control mean })_{\mathrm{t}}} \times 100
$$

Where $\mathrm{t}=$ time

\section{Hot plate method}

The analgesic activity of each of the constituent plants of Nefang was tested using the hot plate method described by Janssen and Jagenea [18], with modifications. Ninety-two mice were randomly divided into twenty three groups of four mice each. Group 1 was treated with $0.1 \mathrm{~mL}$ of normal saline, group 2 - the reference drugs (piroxicam, $20 \mathrm{mgkg}^{-1}$ and pethidine, $50 \mathrm{mgkg}^{-1}$ ), while the remaining twenty one groups were divided into three groups per extract and treated with 300, 600 and $1200 \mathrm{mgkg}^{-1}$ bwt of each extract respectively. An inverted $500 \mathrm{~mL}$ glass conical flask on a clamp and stand was connected by rubber tubing to a hot water bath with thermostat and pump, to enable free circulation of water. The temperature was regulated to $55{ }^{\circ} \mathrm{C}$, such that the temperature on the surface of the inverted conical flask was the same as that of the water bath. Each mouse was then placed on the conical flask in order to obtain its response to heat-induced nociceptive pain stimulus. Licking of the forepaws and eventually jumping off the conical flask was taken as an indicator of the animal's response to heat-induced nociceptive pain stimulus. The reaction time for each mouse was recorded in seconds. Readings were taken at time zero before administration of drugs/extracts and after that at intervals of 30, 60 and $120 \mathrm{~min}$. Cut off time in the absence of response was $60 \mathrm{~s}$ to avoid tissue damage. The percentage of pain inhibition was calculated for each group using the following equation:

$$
\text { Percentage inhibition }=\frac{(\text { Test mean })_{t}-(\text { Control mean })_{t}}{(\text { Control mean })_{t}} \times 100
$$

Where $\mathrm{t}=$ time

\section{Statistical analysis}

Data are expressed as mean \pm standard deviation (SD). Data were analyzed using Windows SPSS Version 20.0
(SPSS Inc. Chicago, IL, USA). One-way analysis of variance (ANOVA) followed by Neuman-Keuls multiple comparison test to identify the differences between treated groups and controls. The data was considered significant at $P<0.05$.

\section{Results \\ Antipyretic activity \\ Effects on D-Amphetamine-induced pyrexia}

Antipyretic activities of the constituent plant extracts of Nefang were evaluated using D-amphetamine induced pyrexia in experimental animals. The change in body temperature and the percentage inhibition of induced pyrexia by the constituent extracts have been summarized in Table 1. In rats treated with the standard drug, paracetamol $\left(150 \mathrm{mgkg}^{-1}\right)$, we observed an initial rise in body temperature of approximately $1{ }^{\circ} \mathrm{C}$ after $30 \mathrm{~min}$. The highest rise in body temperature observed after $60 \mathrm{~min}$ was less than $2{ }^{\circ} \mathrm{C}$. However, after $120 \mathrm{~min}$ we observed a significant $(p<0.05)$ decrease in body temperature when compared to the control. This decrease to normal body temperature after $240 \mathrm{~min}$, was significantly $(p<0.001)$ lower when compared to that of the control.

Upon administration of the constituent plant extracts of Nefang, we observed the same rise in body temperature after $30 \mathrm{~min}$ in all groups, with highest body temperatures attained after about $60 \mathrm{~min}$. After $120 \mathrm{~min}$, we observed significant $(p<0.05)$ decrease in body temperatures in animals treated with $C c, O g, M i L, M i B$ and $C s$. After $240 \mathrm{~min}$, we observed that $C c$ exhibited the best activity with pyrexia inhibition of $95 \%$, followed by $M i L$ (90), MiB (88), $O g$ (85) and Cs (82), comparable to the standard drug, paracetamol (100). $P g$ and $C p$ exhibited very weak antipyretic activities in experimental animals.

\section{Effects on brewer's yeast-induced hyperpyrexia}

Antipyretic activities of the constituent plant extracts of Nefang were further evaluated using brewer's yeastinduced hyperpyrexia in experimental animals. The effect on the body temperatures and the percentage inhibition of induced pyrexia by the constituent plant extracts have been summarized in Table 2 . In rats treated with the standard drug, paracetamol $\left(150 \mathrm{mgkg}^{-1}\right)$, we observed the same trend in temperature rise like the previous exercise with D-amphetamine, with body temperatures of experimental animals coming back to normal after $240 \mathrm{~min}$ and significantly $(p<0.001)$ lower when compared to that of the control.

$C c, O g, M i L, M i B$ and $C s$ exhibited significant $(p<0.05)$ better antipyretic activities while $P g$ and $C p$ exhibited lower activities when compared to the control. At the end of $240 \mathrm{~min}, C c$ and $O g$ exhibited percentage pyrexia inhibition of 97 and 94, comparable to the activity of the standard drug paracetamol (95). We observed once again that, 
Table 1 Effect of the aqueous plant extracts of the constituents of Nefang on D-amphetamine-induced pyrexia in wistar rats

\begin{tabular}{|c|c|c|c|c|c|c|c|c|c|c|c|c|}
\hline \multirow{3}{*}{$\begin{array}{l}\text { Treatment (Drug/ } \\
\text { Aqueous Extract) }\end{array}$} & \multirow{3}{*}{$\begin{array}{l}\text { Dose } \\
(\mathrm{mg} / \mathrm{kg})\end{array}$} & \multirow{3}{*}{$\begin{array}{l}\text { Basal } \\
\text { Temperature }\end{array}$} & \multicolumn{10}{|c|}{ Body temperature $[\mathrm{BT}]\left({ }^{\circ} \mathrm{C}\right)$ and pyrexia inhibition $[\mathrm{PI}](\%)$ over time (minutes) $(\bar{x} \pm S \mathrm{D}, \mathrm{n}=4)$} \\
\hline & & & 30 & & 60 & & 120 & & 180 & & 240 & \\
\hline & & & BT & $\mathrm{Pl}$ & BT & $\mathrm{Pl}$ & BT & $\mathrm{Pl}$ & BT & $\mathrm{Pl}$ & BT & $\mathrm{Pl}$ \\
\hline 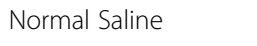 & - & 33 & 19 & 10 & $23 \pm 0.32$ & 0.0 & $36.70 \pm 0.38$ & 0.0 & 36.78 & 0.0 & $36.98 \pm 0.33$ & 0. \\
\hline aracetamol & 150 & $34.98 \pm 0.42$ & $35.85 \pm 0.24$ & 15.5 & $36.18 \pm 0.28$ & 15.9 & $36.08 \pm 0.19^{*}$ & 37.1 & $35.28 \pm 0.29^{*}$ & 78.1 & $34.98 \pm 0.17^{* *}$ & 100 \\
\hline \multirow[t]{2}{*}{ Mangifera indica bark } & 200 & .10 & $36.40 \pm 0.14$ & 0.0 & $35.90 \pm 0.22$ & 31.4 & $35.60 \pm 0.16^{*}$ & 67.1 & $35.45 \pm 0.13^{*}$ & 76.7 & $35.25 \pm 0.33^{*}$ & 88 \\
\hline & 400 & $35.00 \pm 0.08$ & $36.55 \pm 0.21$ & 0.0 & $36.03 \pm 0.15$ & 19.6 & $35.68 \pm 0.22^{*}$ & 61.4 & $35.45 \pm 0.17^{*}$ & 75.3 & $35.33 \pm 0.24^{*}$ & 84 \\
\hline \multirow[t]{2}{*}{ Mangifera indica leaf } & 200 & 8 & 36.05 & 0.0 & 35 & 23.5 & $35.75 \pm$ & 57.1 & 35.43 & 76.7 & 35 & $87-7-3$ \\
\hline & 400 & 47 & 50.6 & 0.0 & $36.78=$ & 0.0 & $36.08 \pm 0.10^{*}$ & 48.6 & $35.85 \pm 0.45^{*}$ & 63.0 & $35.38 \pm 0.37^{*}$ & 90. \\
\hline \multirow[t]{2}{*}{ Psidium guajava leaf } & 200 & $35.18 \pm 0.39$ & $36.13 \pm 0.26$ & 0.0 & $36.35 \pm 0.37$ & 7.8 & $36.80 \pm 0.14$ & 7.1 & $36.63 \pm 0.19$ & 20.5 & $36.45 \pm 0.06$ & 37 \\
\hline & 400 & ( & $36.05=$ & 0.0 & $36.50 \pm 0.54$ & 0.0 & $36.68 \pm 0.13$ & 12.9 & $36.40 \pm 0.14$ & 31.5 & $36.45 \pm 0.33$ & 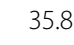 \\
\hline \multirow[t]{2}{*}{ Carica papaya leaf } & 20 & $35.05 \pm$ & 36.48 & 0.0 & $36.53 \pm 0.43$ & 0.0 & $36.78 \pm 0.49$ & 1.4 & $36.80 \pm 0.48$ & 4.1 & 36.68 & 19. \\
\hline & 400 & $35.00 \pm 0$ & $36.45 \pm$ & .0 & $36.63 \pm 0.93$ & 0.0 & $36.70 \pm 0.22$ & 2.9 & $36.75 \pm 0.5$ & 4.1 & $36.75 \pm 0.37$ & $12+2$ \\
\hline \multirow{2}{*}{$\begin{array}{l}\text { Cymbopogon citratus } \\
\text { leaf }\end{array}$} & 200 & $35.05 \pm$ & $36.10 \pm 0.08$ & 0.0 & $35.88 \pm 0.22$ & 35.3 & $35.50 \pm 0.38^{*}$ & 74.3 & $35.20 \pm 0.41^{*}$ & 91.8 & $35.15 \pm 0.17^{* *}$ & 95. \\
\hline & 400 & $34.90 \pm 0.29$ & $35.85 \pm 0.06$ & 0.0 & $35.75 \pm$ & 33.3 & $35.43 \pm 0.33^{*}$ & 70.0 & 35.23 & 82.2 & $0.18^{* *}$ & 8 \\
\hline \multirow[t]{2}{*}{ Citrus sinensis leaf } & 200 & $34.90 \pm 0.08$ & $35.73 \pm 0.13$ & 0.0 & $36.05 \pm 0.13$ & 9.8 & $35.73 \pm 0.15^{*}$ & 52.9 & $35.50 \pm 0.12^{*}$ & 67.1 & $35.28 \pm 0.22^{* *}$ & 81.5 \\
\hline & 400 & $34.98 \pm 0.15$ & $35.93 \pm 0.10$ & 0.0 & $36.08 \pm 0.28$ & 13.7 & $35.88 \pm 0.15^{*}$ & 48.6 & $35.58 \pm 0.32^{*}$ & 67.1 & $35.33 \pm 0.22^{* *}$ & 82. \\
\hline \multirow{2}{*}{$\begin{array}{l}\text { Ocinum gratissimum } \\
\text { leaf }\end{array}$} & 200 & $34.93 \pm 0.13$ & $35.63 \pm 0.36$ & 15.1 & $35.80 \pm 0.36$ & 31.4 & $35.58 \pm 0.36^{*}$ & 62.9 & $35.28 \pm 0.66^{*}$ & 80.8 & $35.28 \pm 0.71^{* *}$ & 82.7 \\
\hline & 400 & $34.90 \pm 0.16$ & $35.95 \pm 0.17$ & 0.0 & $36.05 \pm 0.17$ & 9.8 & $35.88 \pm 0.13^{*}$ & 44.3 & $35.25 \pm 0.32^{*}$ & 80.8 & $35.20 \pm 0.22^{* *}$ & $\varepsilon$ \\
\hline
\end{tabular}

Siginificant difference ${ }^{*}-p<0.05 .{ }^{*}-p<0.001$ when compare to the control

Table 2 Effect of the aqueous extracts of the constituent plants of Nefang on Brewer's Yeast-induced hyperpyrexia in wistar rats

\begin{tabular}{|c|c|c|c|c|c|c|c|c|c|c|c|c|}
\hline \multirow{3}{*}{$\begin{array}{l}\text { Treatment (Drug/ } \\
\text { Aqueous Extract) }\end{array}$} & \multirow{3}{*}{$\begin{array}{l}\text { Dose } \\
(\mathrm{mg} / \mathrm{kg})\end{array}$} & \multirow{3}{*}{$\begin{array}{l}\text { Basal } \\
\text { Temperature }\end{array}$} & \multicolumn{10}{|c|}{ Body temperature $[\mathrm{BT}]\left({ }^{\circ} \mathrm{C}\right)$ and pyrexia inhibition $[\mathrm{PI}](\%)$ over time (minutes) $(\overline{\mathrm{x}} \pm \mathrm{SD}, \mathrm{n}=4)$} \\
\hline & & & 30 & & 60 & & 120 & & 180 & & 240 & \\
\hline & & & BT & $\mathrm{Pl}$ & BT & $\mathrm{Pl}$ & BT & $\mathrm{Pl}$ & BT & $\mathrm{Pl}$ & BT & $\mathrm{Pl}$ \\
\hline ormal Saline & - & $37.00 \pm 0.29$ & $37.95 \pm 0.21$ & 0.0 & $38.14 \pm 0.38$ & 0.0 & $38.65 \pm 0.32$ & 0.0 & $38.91 \pm 0.11$ & 0.0 & $38.96 \pm 0.54$ & 0 \\
\hline nol & 150 & 38 & $70 \pm 0.45$ & 15.8 & $37.75 \pm$ & 25.4 & $37.85=$ & 42.4 & $37.47 \pm 0.26^{*}$ & 70.2 & $37.00 \pm 0.39^{* *}$ & 94. \\
\hline \multirow[t]{2}{*}{ Mangifera indica bark } & 200 & $36.90 \pm 0.31$ & $37.85 \pm 0.39$ & 0.0 & $37.90 \pm 0.41$ & 12.3 & $37.75 \pm 0.27^{*}$ & 48.5 & $37.55 \pm 0.25^{*}$ & 66.0 & $37.20 \pm 0.41^{*}$ & 84 \\
\hline & 400 & 3605 & 0.27 & 0.0 & $38.15 \pm$ & 0.0 & $37.73 \pm 0.31^{*}$ & 52.7 & $37.50 \pm 0.19^{*}$ & 71.2 & $37.30 \pm 0.38^{*}$ & 82 \\
\hline \multirow[t]{2}{*}{ Mangifera indica leaf } & 200 & $37.00 \pm 0.74$ & $37.85 \pm 0.16$ & 10.5 & $37.95 \pm 0.37$ & 16.7 & $37.60 \pm 0.18^{*}$ & 63.6 & $37.35 \pm 0.11^{*}$ & 81.7 & $37.20 \pm 0.28^{*}$ & 89 \\
\hline & 400 & $37.05 \pm 0.67$ & $38.45 \pm 0.43$ & 0.0 & 38.60 & 0.0 & 38.25 & 27.3 & $37.90 \pm 0.28^{*}$ & 55.5 & 37.50 & 年 \\
\hline \multirow[t]{2}{*}{ Psidium guajava leaf } & 200 & $36.95 \pm 0.51$ & $38.00 \pm 0.54$ & 0.0 & $38.40 \pm 0.61$ & 0.0 & $38.70 \pm 0.19$ & 0.0 & $38.65 \pm 0.38$ & 11.0 & $38.50 \pm 0.17$ & 20 \\
\hline & 400 & $37.10 \pm 0.33$ & $38.00 \pm 0.15$ & 5.3 & $38.65 \pm 0.72$ & 0.0 & $38.75 \pm 0.24$ & 0.0 & $38.55 \pm 0.36$ & 24.1 & $38.45 \pm$ & 3 \\
\hline \multirow[t]{2}{*}{ Carica papaya leaf } & 200 & $37.00 \pm 0.61$ & $38.25 \pm 0.27$ & 0.0 & $38.60 \pm 0.36$ & 0.0 & $38.68 \pm 0.22$ & 0.0 & $38.65 \pm 0.31$ & 13.6 & $38.60 \pm 0.26$ & 18 \\
\hline & 400 & $36.90 \pm 0.68$ & $37.90 \pm 0.51$ & 0.0 & $38.45 \pm 0.29$ & 0.0 & $38.65 \pm 0.31$ & 0.0 & $38.70 \pm 0.29$ & 5.8 & 38.60 & 13 \\
\hline \multirow{2}{*}{$\begin{array}{l}\text { Cymbopogon citratus } \\
\text { leaf }\end{array}$} & 200 & $36.95 \pm 0.28$ & $37.90 \pm 0.89$ & 0.0 & $37.85 \pm$ & 21.1 & $37.45 \pm 0.35^{*}$ & 69.7 & $37.20 \pm 0.52^{*}$ & 86.9 & $37.00 \pm 0.09^{* *}$ & 97 \\
\hline & 400 & $37.00 \pm 0.41$ & $38.05 \pm 0.62$ & 0.0 & $37.70 \pm 0.09$ & 38.6 & $37.45 \pm 0.18^{*}$ & 72.7 & $37.30 \pm 0.56^{*}$ & 84.3 & $37.05 \pm 0.22^{* *}$ & 97 \\
\hline \multirow[t]{2}{*}{ Citrus sinensis leaf } & 200 & $37.00 \pm 0.22$ & $38.00 \pm 0.20$ & 0.0 & $38.05 \pm 0.25$ & 7.9 & $37.85 \pm 0.26^{*}$ & 48.5 & $37.55 \pm 0.19^{*}$ & 71.2 & $37.35 \pm 0.35^{*}$ & 82 \\
\hline & 400 & $37.05 \pm 0.15$ & $38.05 \pm 0.31$ & 0.0 & $38.25 \pm 0.18$ & 0.0 & $37.75 \pm 0.11^{*}$ & 57.6 & $37.45 \pm 0.55^{*}$ & 79.1 & $37.25 \pm 0.28^{*}$ & 89. \\
\hline \multirow{2}{*}{$\begin{array}{l}\text { Ocimumgratissimum } \\
\text { leaf }\end{array}$} & 200 & $37.00 \pm 0.33$ & $37.95 \pm 0.46$ & 0.0 & $37.90 \pm 0.42$ & 21.1 & $37.75 \pm 0.19^{*}$ & 54.5 & $37.40 \pm 0.38^{*}$ & 79.1 & $37.15 \pm 0.52^{* *}$ & 92 \\
\hline & 400 & $37.00 \pm 0.81$ & $37.95 \pm 0.19$ & 0.0 & $38.00 \pm 0.19$ & 12.3 & $37.75 \pm 0.09^{*}$ & 54.5 & $37.45 \pm 0.61^{*}$ & 76.4 & $37.10 \pm 0.33^{* *}$ & 94. \\
\hline
\end{tabular}


$C c$ exhibited the best activity among all the extracts tested. We also observed that pyrexia inhibition trends by the constituent plant extracts and the standards were comparable in both methods.

\section{Anti-inflammatory activity}

The anti-inflammatory activities of the constituent plant extracts of Nefang at different concentrations (100, 200 and $400 \mathrm{mgkg}^{-1}$ ) were determined using Indomethacin (10 $\left.\mathrm{mgkg}^{-1}\right)$ as the standard. Results obtained have been summarized in Table 3. These indicated significant inhibition of carrageenan-induced inflammation in paws of experimental rats when compared to the control. Inflammation of the paw of experimental animals was observed $60 \mathrm{~min}$ post carrageenan administration. In experimental rats treated with the standard drug, the paw volumes were significantly $(p<0.001)$ reduced, 240 min post administration, giving a paw edema inhibition of $43.7 \%$ when compared to the control. After administration of the constituent plant extracts of Nefang, only MiL exhibited a comparable anti- inflammatory activity to that of the standard drug by significantly $(p<0.001)$ reducing the inflamed rat paw volumes by $40 \%$ at all doses. $C p$ and $M i B$ also exhibited significant $(p<0.05)$ anti-inflammatory activities at lower doses in experimental rats when compared to the control, with approximately $28-30 \%$ paw inhibition. $\mathrm{Og}, \mathrm{Pg}, \mathrm{Cc}$ and $C s$ all showed moderate but significant $(p<0.05)$ antiinflammatory activities at lower doses, with paw inhibition of approximately $20 \%$.

\section{Antinociceptive activity \\ Effects on tail pressure}

The antinociceptive activity of the constituent plant extracts of Nefang on tail-induced pressure in mice was determined using an analgesy-meter. The percentage inhibition of induced pain in experimental mice, calculated from their mean reaction times to gradual increase in tail pressure has been summarized in Fig. 1. The results obtained suggested that $M i L, O g$ and $P g$ produced significant $(p<0.001)$ percentage inhibition of the threshold

Table 3 Anti-inflammatory effect of the constituent plant extracts of Nefang on carrangeenan-induced paw edema in wistar rats

\begin{tabular}{|c|c|c|c|c|c|c|c|c|c|c|}
\hline \multirow[t]{3}{*}{ Treatment (Drug/Aqueous Extract) } & \multirow[t]{3}{*}{ Dose $(\mathrm{mg} / \mathrm{kg})$} & \multicolumn{9}{|c|}{$\begin{array}{l}\text { Increase in paw volumes [PV] }(\mathrm{mL}) \text { and edema inhibition [El] (\%) over time (minutes) } \\
(\overline{\mathrm{x}} \pm \mathrm{SD}, \mathrm{n}=5)\end{array}$} \\
\hline & & \multirow[t]{2}{*}{0} & \multicolumn{2}{|l|}{60} & \multicolumn{2}{|l|}{120} & \multicolumn{2}{|l|}{180} & \multicolumn{2}{|l|}{240} \\
\hline & & & PV & El & PV & El & PV & El & PV & El \\
\hline Normal Saline & - & 0 & $1.18 \pm 0.08$ & 0.0 & $1.28 \pm 0.14$ & 0.0 & $1.46 \pm 0.13$ & 0.0 & $1.56 \pm 0.09$ & 0.0 \\
\hline Indomethacin & 10 & 0 & $1.17 \pm 0.04$ & 1.3 & $1.08 \pm 0.03^{*}$ & 15.3 & $1.00 \pm 0.10^{* *}$ & 31.5 & $0.88 \pm 0.03^{* *}$ & 43.7 \\
\hline \multirow[t]{3}{*}{ Mangifera indica bark } & 100 & 0 & $1.07 \pm 0.11$ & 9.7 & $1.13 \pm 0.09^{*}$ & 11.4 & $1.19 \pm 0.03^{*}$ & 18.8 & $1.12 \pm 0.01^{* *}$ & 28.3 \\
\hline & 200 & 0 & $1.15 \pm 0.12$ & 3.0 & $1.21 \pm 0.02$ & 5.5 & $1.32 \pm 0.06^{*}$ & 9.9 & $1.24 \pm 0.10^{*}$ & 20.6 \\
\hline & 400 & 0 & $1.18 \pm 0.05$ & 0.4 & $1.27 \pm 0.04$ & 0.8 & $1.36 \pm 0.03$ & 6.8 & $1.26 \pm 0.06^{*}$ & 19.0 \\
\hline \multirow[t]{3}{*}{ Mangifera indica leaf } & 100 & 0 & $1.04 \pm 0.13$ & 11.9 & $1.01 \pm 0.08^{*}$ & 20.8 & $0.92 \pm 0.08^{* *}$ & 37.3 & $0.93 \pm 0.06^{* *}$ & 40.2 \\
\hline & 200 & 0 & $1.05 \pm 0.03$ & 11.4 & $1.11 \pm 0.08^{*}$ & 13.3 & $0.91 \pm 0.14^{* *}$ & 37.7 & $0.95 \pm 0.11^{* *}$ & 39.2 \\
\hline & 400 & 0 & $1.05 \pm 0.03$ & 11.4 & $0.93 \pm 0.03^{*}$ & 27.5 & $0.89 \pm 0.06^{* *}$ & 39.4 & $0.88 \pm 0.08^{* *}$ & 43.4 \\
\hline \multirow[t]{3}{*}{ Psidium guajava leaf } & 100 & 0 & $1.04 \pm 0.04$ & 11.9 & $1.12 \pm 0.10^{*}$ & 12.5 & $1.12 \pm 0.06^{*}$ & 23.6 & $1.21 \pm 0.04^{*}$ & 22.2 \\
\hline & 200 & 0 & $1.04 \pm 0.07$ & 11.9 & $1.14 \pm 0.11^{*}$ & 11.0 & $1.13 \pm 0.13^{*}$ & 22.6 & $1.23 \pm 0.13^{*}$ & 21.2 \\
\hline & 400 & 0 & $1.08 \pm 0.07$ & 8.5 & $1.17 \pm 0.10^{*}$ & 8.2 & $1.27 \pm 0.15^{*}$ & 13.0 & $1.28 \pm 0.05^{*}$ & 17.7 \\
\hline \multirow[t]{3}{*}{ Carica papaya leaf } & 100 & 0 & $0.97 \pm 0.03$ & 17.8 & $1.04 \pm 0.10^{*}$ & 18.4 & $1.15 \pm 0.09^{* *}$ & 21.2 & $1.10 \pm 0.03^{* *}$ & 29.3 \\
\hline & 200 & 0 & $1.10 \pm 0.09$ & 6.8 & $1.12 \pm 0.17^{*}$ & 12.5 & $1.17 \pm 0.13^{* *}$ & 19.9 & $1.11 \pm 0.05^{* *}$ & 28.9 \\
\hline & 400 & 0 & $1.11 \pm 0.07$ & 6.4 & $1.19 \pm 0.05$ & 6.7 & $1.36 \pm 0.11$ & 7.2 & $1.32 \pm 0.09^{*}$ & 15.1 \\
\hline \multirow[t]{3}{*}{ Cymbopogon citratus leaf } & 100 & 0 & $1.08 \pm 0.12$ & 8.9 & $1.16 \pm 0.04^{*}$ & 9.4 & $1.24 \pm 0.11^{*}$ & 15.1 & $1.27 \pm 0.03^{*}$ & 18.3 \\
\hline & 200 & 0 & $1.12 \pm 0.04$ & 5.1 & $1.17 \pm 0.08^{*}$ & 8.2 & $1.20 \pm 0.02^{*}$ & 18.2 & $1.34 \pm 0.04^{*}$ & 13.8 \\
\hline & 400 & 0 & $1.15 \pm 0.04$ & 3.0 & $1.24 \pm 0.01$ & 3.1 & $1.42 \pm 0.06$ & 3.1 & $1.48 \pm 0.09$ & 5.1 \\
\hline \multirow[t]{3}{*}{ Citrus sinensis leaf } & 100 & 0 & $1.15 \pm 0.12$ & 2.5 & $1.22 \pm 0.03$ & 4.7 & $1.24 \pm 0.05^{*}$ & 15.1 & $1.27 \pm 0.13^{*}$ & 18.6 \\
\hline & 200 & 0 & $1.17 \pm 0.03$ & 1.3 & $1.19 \pm 0.04$ & 7.1 & $1.35 \pm 0.20$ & 7.5 & $1.46 \pm 0.16$ & 6.4 \\
\hline & 400 & 0 & $1.17 \pm 0.04$ & 0.8 & $1.20 \pm 0.03$ & 6.3 & $1.45 \pm 0.04$ & 1.0 & $1.56 \pm 0.13$ & 0.0 \\
\hline \multirow[t]{3}{*}{ Ocimum gratissimum leaf } & 100 & 0 & $1.06 \pm 0.05$ & 10.6 & $1.14 \pm 0.07^{*}$ & 10.6 & $1.23 \pm 0.04^{*}$ & 16.1 & $1.22 \pm 0.05^{*}$ & 21.5 \\
\hline & 200 & 0 & $1.07 \pm 0.06$ & 9.3 & $1.16 \pm 0.08^{*}$ & 9.4 & $1.23 \pm 0.04^{*}$ & 16.1 & $1.24 \pm 0.02^{*}$ & 20.3 \\
\hline & 400 & 0 & $1.17 \pm 0.03$ & 1.3 & $1.26 \pm 0.04$ & 1.2 & $1.31 \pm 0.12$ & 10.3 & $1.33 \pm 0.08$ & 14.5 \\
\hline
\end{tabular}


pain by $177.3,167.4$ and 139.6 respectively, when compared to the normal control $30 \mathrm{~min}$ after extract administration. This activity was comparable to that of the standard drug, morphine (146.7 \%). MiB and $C p$ had moderate percentage pain inhibition of 107.7 and 106.3 respectively while $C s$ and $C c$ had weak activities. Two hours post treatment, only $M i L$ and $O g$ still exhibited good pain inhibition levels of $129.6 \%$ and $112.2 \%$ respectively, comparable to $146.7 \%$ for morphine. $P g$ and $M i B$ still exhibited moderate activities at $83.3 \%$ and 77.4 \%, while $C c, C p$ and $C s$ exhibited very weak activities. Since all the extracts showed activity, they were all subjected to further dose-response testing.

\section{Tail flick response}

The results of the tail flick response in mice and the calculated percentage inhibition by the constituent plant extracts of Nefang have been presented in Table 4. In experimental animals treated with the standard drug, paracetamol, the mean initial tail flicking time was $4.27 \mathrm{~s}$. The reaction time increased gradually after administration of the standard drug and a mean reaction time of $8.39 \mathrm{~s}$ was attained at the end of $60 \mathrm{~min}$. This was constant up to the end of $120 \mathrm{~min}$. Analysis revealed that $O g, M i L, P g$ and $M i B$ exhibited dose-dependent increases in reaction time. The reaction times after administration of $M i L$ and $P g$ at doses of 600 and $1200 \mathrm{mgkg}^{-1}$ bwt, were comparable to that of the standard group after $60 \mathrm{~min}$ and up to $120 \mathrm{~min}$, whereas animals treated with $O g$ and $M i B$ exhibited the same activity only at the highest dose of $1200 \mathrm{mgkg}^{-1}$. The mean initial tail flicking time resulted in a pain inhibition of $59.9 \%$ after $30 \mathrm{~min}$ to over $90 \%$ after $60 \mathrm{~min}$, which was constant to the end of the experiment (120 min), when compared to the reaction before drug administration. Pain inhibition (\%) at the highest doses for $O g$ (113), MiL (108), $P g(84)$ and $M i B$ (88) were comparable to that of paracetamol (97).
At lower doses, we observed significantly $(p<0.05)$ lower activities of these extracts when compared to the standard. In animals administered $C p$ and $C c$, we observed moderate reaction times at doses up to $600 \mathrm{mgkg}^{-1}$ bwt, though significantly $(p<0.05)$ low when compared to the standard. At higher doses as well as in animals treated with $C s$ (all doses), reaction times were significantly $(p<0.001)$ low, suggesting that they exhibited lower activities.

\section{Hot plate response}

The effect of the constituent plants of Nefang on heatinduced nociceptive pain in mice was determined using the hot plate method (Table 5). Piroxicam $\left(20 \mathrm{mgkg}^{-1}\right)$ and pethidine $\left(50 \mathrm{mgkg}^{-1}\right)$ were used as standards. The reaction times of experimental animals were taken after 30 , 60 and $120 \mathrm{~min}$. Piroxicam-treated rats exhibited reactions times of 19.31, 47.49 and $47.41 \mathrm{~s}$ and pethidine-treated rats, $18.90,19.15$ and $20.02 \mathrm{~s}$. These produced significant percentage increase in the threshold of pain by $87.7,361.6$, $360.8(p<0.01)$ and 100.2, 102.8, $112.0(p<0.05)$ respectively, suggesting that piroxicam exhibited a better antinociceptive activity than pethidine relative to the control.

After administration of the plants extracts, we observed a dose-dependent increase in reaction times in animals treated with $O g, M i L, M i B$ and $P g$ between 30 to $120 \mathrm{~min}$, with $O g$ showing the best reaction time of $28.98,29.94$ and $32.55 \mathrm{~s}$ after 30,60 and $120 \mathrm{~s}$ respectively, at the highest dose of $1200 \mathrm{mgkg}^{-1}$. This corresponds to an increased percentage pain inhibition of 187.7, 197.2 and 223.1 during the experimental time; this was significantly $(p<0.001)$ lower than that of piroxicam after $120 \mathrm{~min}$ and higher than that of pethidine $(p<0.001) . M i L, M i B$ and $P g$ all showed significantly $(p<0.001)$ higher pain inhibition at $1200 \mathrm{mgkg}^{-1}$ in experimental animals when compared to animals that were treated with pethidine, though lower when compared to animals that were administered piroxicam. $C p, C c$ and $C s$ exhibited weak activities $(p<0.001)$.

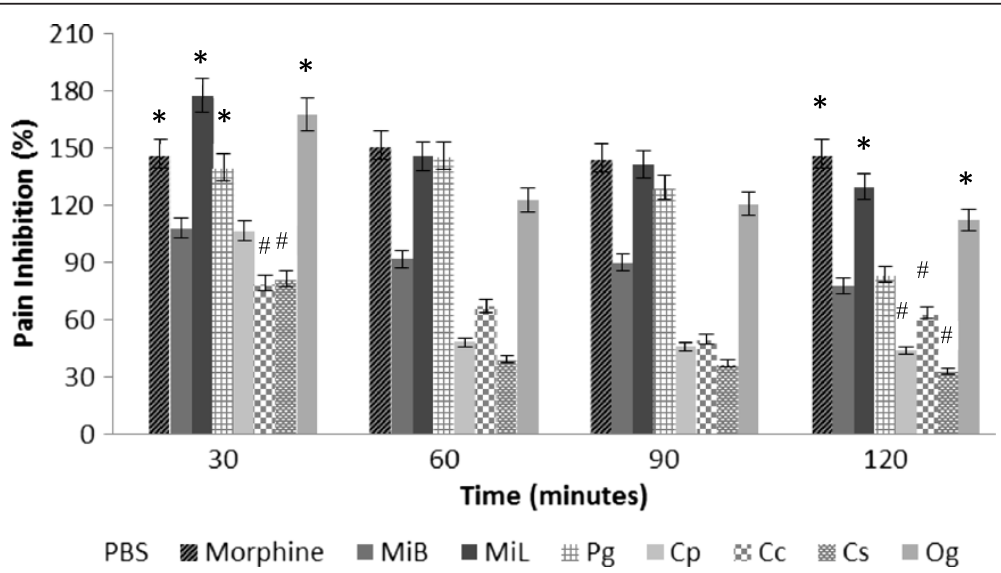

Fig. 1 Antinociceptive effect of the constituent plant extracts of Nefang on tail-induced pressure in mice. Significant difference: ${ }^{*}-p<0.001$ when compared to normal control; \# - $p<0.05$ when compared to the standard 
Table 4 Antinociceptive effect of the constituent plant extracts of Nefang on electric heat-induced pain on the tails of mice

\begin{tabular}{|c|c|c|c|c|c|c|c|c|c|c|}
\hline \multirow[t]{3}{*}{ Treatment (Drug/Aqueous Extract) } & \multirow[t]{3}{*}{ Dose $(\mathrm{mg} / \mathrm{kg})$} & \multicolumn{9}{|c|}{$\begin{array}{l}\text { Tail flick reaction time }[R T](\mathrm{sec}) \text { and pain inhibition }[\mathrm{PI}](\%) \text { at designated time intervals (minutes) } \\
(\mathrm{x} \pm \mathrm{SD}, \mathrm{n}=5)\end{array}$} \\
\hline & & \multirow{2}{*}{$\begin{array}{l}0 \\
\text { RT }\end{array}$} & \multicolumn{2}{|l|}{30} & \multicolumn{2}{|l|}{60} & \multicolumn{2}{|l|}{90} & \multicolumn{2}{|l|}{120} \\
\hline & & & RT & $\mathrm{PI}$ & RT & $\mathrm{Pl}$ & RT & $\mathrm{Pl}$ & RT & $\mathrm{Pl}$ \\
\hline Paracetamol & 150 & $4.27 \pm 0.38$ & $6.82 \pm 0.28$ & 60.0 & $8.39 \pm 0.20$ & 96.8 & $8.43 \pm 0.36$ & 97.6 & $8.26 \pm 0.23$ & 93.5 \\
\hline \multirow[t]{3}{*}{ Mangifera indica bark } & 300 & $4.30 \pm 0.38$ & $5.62 \pm 0.24$ & 31.7 & $6.47 \pm 0.37$ & 51.7 & $6.30 \pm 0.31^{*}$ & 47.6 & $5.66 \pm 0.24^{*}$ & 32.7 \\
\hline & 600 & $4.30 \pm 0.38$ & $5.96 \pm 0.49$ & 39.6 & $6.46 \pm 0.37^{*}$ & 51.5 & $6.35 \pm 0.25^{*}$ & 48.8 & $6.25 \pm 0.20^{*}$ & 46.5 \\
\hline & 1200 & $4.30 \pm 0.38$ & $7.20 \pm 0.27$ & 68.8 & $8.05 \pm 0.41$ & 88.7 & $6.99 \pm 0.29$ & 63.8 & $6.98 \pm 0.06$ & 63.6 \\
\hline \multirow[t]{3}{*}{ Mangifera indica leaf } & 300 & $4.32 \pm 0.38$ & $6.47 \pm 0.25$ & 51.8 & $7.59 \pm 0.43$ & 77.9 & $6.19 \pm 0.37^{*}$ & 45.1 & $6.08 \pm 0.20^{*}$ & 42.6 \\
\hline & 600 & $4.32 \pm 0.38$ & $6.95 \pm 0.14$ & 62.9 & $7.80 \pm 0.21$ & 82.2 & $7.78 \pm 0.76$ & 82.4 & 7.47 & 75.1 \\
\hline & 1200 & $4.32 \pm 0.38$ & $7.09 \pm 0.48$ & 66.1 & $8.89 \pm 0.41$ & 108.5 & $8.64 \pm 0.44$ & 102.6 & $8.42 \pm 0.36$ & 97.3 \\
\hline \multirow[t]{3}{*}{ Psidium guajava leaf } & 300 & $4.25 \pm 0.38$ & $6.32 \pm 0.35$ & 49.3 & $6.49 \pm 0.29$ & 52.2 & $6.38 \pm 0.17^{*}$ & 49.6 & $5.26 \pm 0.17^{*}$ & 23.2 \\
\hline & 600 & $4.25 \pm 0.38$ & $7.63 \pm 0.38$ & 78.8 & $7.73 \pm 0.27$ & 81.2 & $7.42 \pm 0.46$ & 73.8 & $6.45 \pm 0.31^{*}$ & 51.2 \\
\hline & 1200 & $4.25 \pm 0.38$ & $7.82 \pm 0.35$ & 83.3 & $7.88 \pm 0.19$ & 84.7 & $7.54 \pm 0.37$ & 76.7 & $7.08 \pm 0.05$ & 65.9 \\
\hline \multirow[t]{3}{*}{ Carica papaya leaf } & 300 & $4.29 \pm 0.38$ & $5.80 \pm 0.70^{*}$ & 36.1 & $6.35 \pm 0.31^{*}$ & 48.9 & $6.19 \pm 0.53^{*}$ & 45.1 & $5.98 \pm 0.17^{*}$ & 40.2 \\
\hline & 600 & $4.29 \pm 0.38$ & $6.73 \pm 0.87$ & 57.8 & $6.65 \pm 0.52$ & 55.8 & $6.34 \pm 0.48^{*}$ & 48.7 & $6.16 \pm 0.27^{*}$ & 44.4 \\
\hline & 1200 & $4.29 \pm 0.38$ & $5.04 \pm 0.62^{*}$ & 18.2 & $5.12 \pm 0.39^{*}$ & 20.1 & $5.39 \pm 0.63^{*}$ & 26.3 & $5.36 \pm 0.29^{*}$ & 25.7 \\
\hline \multirow[t]{3}{*}{ Cymbopogon citratus leaf } & 300 & $4.31 \pm 0.38$ & $5.42 \pm 0.50^{*}$ & 27.0 & $6.22 \pm 0.28^{*}$ & 45.8 & $5.48 \pm 0.09$ & 28.4 & $5.00 \pm 0.38^{*}$ & 17.3 \\
\hline & 600 & $4.31 \pm 0.38$ & $6.00 \pm 0.90$ & 40.6 & $6.43 \pm 0.33$ & 50.8 & $5.98 \pm 0.30^{*}$ & 40.1 & $5.74 \pm 0.38^{*}$ & 34.5 \\
\hline & 1200 & $4.31 \pm 0.38$ & $5.87 \pm 0.32$ & 37.6 & $6.56 \pm 0.41$ & 53.7 & $5.80 \pm 0.25^{*}$ & 36.0 & $5.69 \pm 0.32^{*}$ & 33.4 \\
\hline \multirow[t]{3}{*}{ Citrus sinensis leaf } & 300 & $4.27 \pm 0.38$ & $4.76 \pm 0.17^{*}$ & 11.6 & $4.77 \pm 0.31^{* *}$ & 11.7 & $4.61 \pm 0.32^{* *}$ & 8.0 & $4.30 \pm 0.22^{* *}$ & 0.9 \\
\hline & 600 & $4.27 \pm 0.38$ & $4.92 \pm 0.28^{*}$ & 15.4 & $4.59 \pm 0.33^{* *}$ & 7.5 & $4.65 \pm 0.42^{* *}$ & 9.1 & $4.35 \pm 0.15^{* *}$ & 1.9 \\
\hline & 1200 & $4.27 \pm 0.38$ & $4.55 \pm 0.30^{*}$ & 6.7 & $4.35 \pm 0.24^{* *}$ & 1.9 & $4.38 \pm 0.15^{* *}$ & 2.8 & $4.26 \pm 0.22^{* *}$ & 0. \\
\hline \multirow[t]{3}{*}{ Ocimum gratissimum leaf } & 300 & $4.33 \pm 0.38$ & $5.58 \pm 0.38$ & 30.8 & $6.33 \pm 0.50^{*}$ & 48.5 & $6.45 \pm 0.26^{*}$ & 51.2 & $5.85 \pm 0.14^{*}$ & 37.0 \\
\hline & 600 & $4.33 \pm 0.38$ & $6.03 \pm 0.76$ & 41.3 & $6.60 \pm 0.54$ & 54.7 & $7.09 \pm 0.68$ & 66.1 & $6.19 \pm 0.30^{*}$ & 45.1 \\
\hline & 1200 & $4.33 \pm 0.38$ & $7.50 \pm 0.55$ & 75.9 & $7.81 \pm 0.29$ & 83.0 & $9.09 \pm 0.69$ & 113.0 & $7.91 \pm 0.38$ & 85.5 \\
\hline
\end{tabular}

Significant difference $*-p<0.05, * *-p<0.001$ when compared to the standard control

\section{Discussion}

Infections such as malaria, caused by Plasmodium species usually trigger a cascade of unpleasant physiological changes in the host such as oxidative stress, pyrexia, inflammation and nociception. Biological agents that can act against these and other relevant effects can complement therapeutic activities of antiparasitic and antimicrobial agents. Activities evaluated in the constituent plants of Nefang included antipyretic, anti-inflammatory and antinociceptive.

Pyrexia is a result of the secondary impact of infection, tissue damage, inflammation, graft rejection, malignancy or other diseased states including malaria. Brewer's yeast and D-amphetamine are commonly used to induce pyrexia in rats and mice [19]. Brewer's yeast induces pyrexia by increasing the synthesis of prostaglandins (PGE2). The infections or damaged tissue serves as a pyrogenic stimulus and the pyrogens are phagocytized by the Kupffer cells, monocytes and macrophages leading to the release of pro-inflammatory mediators (cytokines). These cause an increase in the synthesis of prostaglandins near pre-optic hypothalamus area thereby triggering the hypothalamus to elevate the set point of normal body temperature [20]. Amphetamine on the other hand, acts on the brain causing the release of biogenic amines from their storage sites in nerve terminals. This results in increased level of cyclic-Adenosine monophosphate (cAMP) and subsequent synthesis of prostaglandins from arachidonic acids produced in neurons receptor-mediated hydrolysis of phospholipids, leading to hyperthermia [21]. Most of the antipyretic drugs inhibit cyclooxygenase (COX-2) expression thereby inhibiting prostaglandin biosynthesis and reducing elevated body temperature. They are, however, toxic to the hepatic cells, glomeruli, cortex of the brain and heart muscle. Natural antipyretic remedies with minimal toxicity are therefore essential.

The results of this study show that $C c, O g, M i L, M i B$ and Cs aqueous extracts significantly reduced amphetamine and brewer's yeast induced hyperthermia in the rats at 120 , 180 and 240 min post administration. This hypothermic activity might have been achieved by their action on COX2 , thereby reducing the concentration of prostaglandin in 
Table 5 Antinociceptive effect of the constituent plant extracts of Nefang on heat-induced nociceptive pain in mice

\begin{tabular}{|c|c|c|c|c|c|c|c|c|c|}
\hline \multirow[t]{3}{*}{ Treatment (Drug/Aqueous Extract) } & \multirow[t]{3}{*}{ Dose $(\mathrm{mg} / \mathrm{kg})$} & \multicolumn{8}{|c|}{$\begin{array}{l}\text { Mice reaction time }[\mathrm{RT}](\mathrm{sec}) \text { and pain inhibition }[\mathrm{PI}](\%) \text { at designated time intervals (minutes) } \\
(\overline{\mathrm{x}} \pm \mathrm{SD}, \mathrm{n}=4)\end{array}$} \\
\hline & & \multicolumn{2}{|l|}{$0 \mathrm{~min}$} & \multicolumn{2}{|l|}{$30 \mathrm{~min}$} & \multicolumn{2}{|l|}{$60 \mathrm{~min}$} & \multicolumn{2}{|l|}{$120 \mathrm{~min}$} \\
\hline & & RT & $\mathrm{Pl}$ & RT & $\mathrm{Pl}$ & RT & $\mathrm{Pl}$ & RT & $\mathrm{Pl}$ \\
\hline Normal Saline & - & $9.51 \pm 1.24$ & 0 & $10.70 \pm 1.07$ & 12.6 & $10.56 \pm 0.74$ & 11.0 & $11.28 \pm 0.67$ & 18.6 \\
\hline Piroxicam & 20 & $10.29 \pm 0.61$ & 0 & $19.31 \pm 1.34^{*}$ & 87.7 & $47.49 \pm 0.76^{* *}$ & 361.6 & $47.41 \pm 0.66^{* *}$ & 360.8 \\
\hline Pethidine & 50 & $9.44 \pm 0.17$ & 0 & $18.90 \pm 0.92^{*}$ & 100.2 & $19.15 \pm 0.77^{*}$ & 102.8 & $20.02 \pm 1.14^{*}$ & 112.0 \\
\hline \multirow[t]{3}{*}{ Mangifera indica bark } & 300 & $9.93 \pm 0.25$ & 0 & $13.90 \pm 1.21$ & 40.0 & $21.75 \pm 1.28^{*}$ & 119.0 & $20.81 \pm 0.68^{*}$ & 109.6 \\
\hline & 600 & $9.63 \pm 0.69$ & 0 & $13.65 \pm 0.34$ & 41.8 & $22.23 \pm 0.71^{*}$ & 131.0 & $22.61 \pm 0.70^{*}$ & 134.8 \\
\hline & 1200 & $10.05 \pm 0.26$ & 0 & $22.91 \pm 0.89^{*}$ & 128.0 & $27.29 \pm 0.62^{*}$ & 171.7 & $23.79 \pm 1.81^{*}$ & 136.8 \\
\hline \multirow[t]{3}{*}{ Mangifera indica leaf } & 300 & $11.11 \pm 0.94$ & 0 & $12.80 \pm 0.58$ & 15.2 & $16.71 \pm 0.50^{*}$ & 50.4 & $16.11 \pm 0.26$ & 45.0 \\
\hline & 600 & $11.21 \pm 0.48$ & 0 & $23.72 \pm 0.88^{*}$ & 111.6 & $24.25 \pm 1.17^{*}$ & 116.3 & $21.71 \pm 0.68^{*}$ & 93.7 \\
\hline & 1200 & $10.70 \pm 0.53$ & 0 & $23.41 \pm 1.07^{*}$ & 118.8 & $32.75 \pm 0.25^{* *}$ & 206.1 & $28.56 \pm 0.13^{*}$ & 167.0 \\
\hline \multirow[t]{3}{*}{ Psidium guajava leaf } & 300 & $10.09 \pm 0.45$ & 0 & $14.41 \pm 0.73$ & 42.8 & $14.57 \pm 0.68$ & 44.4 & $13.79 \pm 1.14$ & 36.6 \\
\hline & 600 & $9.84 \pm 0.34$ & 0 & $14.86 \pm 0.51$ & 51.1 & $15.47 \pm 0.21$ & 57.3 & $18.33 \pm 0.29$ & 86.3 \\
\hline & 1200 & $10.29 \pm 0.53$ & 0 & $21.27 \pm 0.46^{*}$ & 106.7 & $26.29 \pm 0.24^{*}$ & 155.4 & $24.22 \pm 0.57^{*}$ & 135.3 \\
\hline \multirow[t]{3}{*}{ Carica papaya leaf } & 300 & $9.63 \pm 0.48$ & 0 & $11.46 \pm 0.94$ & 19.0 & $11.51 \pm 0.36$ & 19.5 & $10.79 \pm 0.61$ & 12.0 \\
\hline & 600 & $9.45 \pm 0.40$ & 0 & $12.28 \pm 0.84$ & 30.0 & $12.51 \pm 0.38$ & 32.5 & $11.01 \pm 0.72$ & 16.6 \\
\hline & 1200 & $9.90 \pm 0.77$ & 0 & $12.45 \pm 0.28$ & 25.8 & $17.42 \pm 0.25^{*}$ & 76.0 & $16.91 \pm 0.62$ & 70.8 \\
\hline \multirow[t]{3}{*}{ Cymbopogon citratus leaf } & 300 & $10.07 \pm 0.34$ & 0 & $11.00 \pm 0.36$ & 9.2 & $11.71 \pm 0.38$ & 16.3 & $15.28 \pm 0.56$ & 51.7 \\
\hline & 600 & $9.78 \pm 0.34$ & 0 & $13.34 \pm 0.77$ & 36.4 & $13.02 \pm 0.45$ & 33.1 & $16.08 \pm 0.72$ & 64.4 \\
\hline & 1200 & $10.05 \pm 0.33$ & 0 & $15.24 \pm 1.12$ & 51.6 & $14.81 \pm 1.10$ & 47.3 & $18.85 \pm 0.57$ & 75.0 \\
\hline \multirow[t]{3}{*}{ Citrus sinensis leaf } & 300 & $9.90 \pm 0.44$ & 0 & $13.24 \pm 0.60$ & 33.7 & $12.83 \pm 0.24$ & 29.6 & $13.27 \pm 0.70$ & 34.1 \\
\hline & 600 & $9.86 \pm 0.46$ & 0 & $15.10 \pm 0.61$ & 53.2 & $14.99 \pm 0.90$ & 52.1 & $13.60 \pm 0.43$ & $38.0 \pm$ \\
\hline & 1200 & $9.73 \pm 0.33$ & 0 & $14.21 \pm 0.67$ & 46.0 & $16.34 \pm 0.60^{*}$ & 67.9 & $15.03 \pm 1.37$ & 54.5 \\
\hline \multirow[t]{3}{*}{ Ocimum gratissimum leaf } & 300 & $9.63 \pm 0.36$ & 0 & $13.66 \pm 0.30$ & 41.8 & $18.15 \pm 0.89^{*}$ & 88.5 & $18.98 \pm 0.92$ & 97.0 \\
\hline & 600 & $9.79 \pm 0.28$ & 0 & $13.66 \pm 0.89$ & 39.5 & $22.83 \pm 0.20^{*}$ & 133.2 & $24.29 \pm 1.17^{*}$ & 148.1 \\
\hline & 1200 & $10.07 \pm 0.70$ & 0 & $28.98 \pm 0.64^{*}$ & 187.7 & $29.94 \pm 0.43^{* *}$ & 197.2 & $32.55 \pm 1.47^{* *}$ & 223.1 \\
\hline
\end{tabular}

Significant difference ${ }^{*}-p<0.05 ; * *-p<0.001$ when compared to the control

the brain or by enhancing the inherent production of the body's own antipyretic substances such as arginine and vasopressin [22]. An alternative could have been by vasodilation of superficial blood vessels leading to increased dissipation of heat as a result of a reset of the hypothalamic temperature control centre [23].

Inflammation is a common phenomenon in malaria infection and it is the reaction of living tissues towards injury. The carrageenan-induced paw edema is a prototype for the exudative phase of acute inflammatory effects. The development of edema in the rat paw after the injection of carrageenan has been described as a biphasic event [24]. The initial phase which starts immediately after injection and reduces within one hour, is attributed to the release of histamine and serotonin, while the second phase of swelling which begins at one and remains through three hours, is due to the release of prostaglandin-like substances [25]. The second phase of edema is sensitive to both clinically useful steroidal and non-steroidal anti-inflammatory drugs
(NSAIDs). Generally NSAIDs strongly inhibit the second phase of carrageenan-induced edema. The significant inhibition of paw edema in rats by $M i L, C p$ and $M i B$ aqueous extracts suggest that they may contain biologically active substances with anti-inflammatory properties. The significant anti-inflammatory activities exhibited may be due to the inhibition of any inflammatory mediators, and this might contribute greatly to the antimalarial activity of Nefang. The co-existence of antinociceptive and antiinflammatory activities observed in Nefang, are properties shared by most NSAIDs, particularly the salicylates and their derivatives. The therapeutic benefits of traditional remedies are often attributed to a combination of active constituents [26].

Increased nociception is a common phenomenon during Plasmodium infection. Measuring antinociceptive activity is based on the principle that inflammation increases the sensitivity to pain and that this sensitivity is susceptible to modification by analgesics. Inflammation decreases the 
pain reaction threshold and this low pain reaction threshold is readily elevated by different types of analgesics [15]. Antinociceptive properties were studied using models that could provide different types of noxious stimuli. These were mechanical pressure on the tail, thermal stimuli using the radiant heat-induced nociceptive pain on the tail and heat-induced nociceptive pain on the paws of mice. Mechanical pain induced by the analgesy-meter provides a model for the study of non-inflammatory pain. The analgesy-meter antinociceptive test is useful in elucidating centrally mediated antinociceptive responses, which focuses mainly on changes above the spinal cord level [27]. The significant increase in pain threshold produced by the extracts in the analgesy-meter test suggests involvement of central pain pathways. Thermal tests have several advantages including the sensitivity to strong analgesics and limited tissue damage [28]. Furthermore, they utilize phasic stimulus of high intensities mimicking responses in conditions that involve high threshold pain of short duration. However, a disadvantage of this model is that since it is short lasting, it does not assess modulatory mechanisms that may be triggered by the stimulus itself [29] and is a less valid model for clinical pain [30]. The results obtained indicate that $O g, M i L, P g$ and $M i B$ can significantly inhibit responses to mechanical and thermal stimuli. The inhibition of thermal stimuli was dose dependent, thus indicating that these extracts, at the doses administered, had strong antinociceptive activities and can contribute significantly to the antimalarial effect of Nefang.

The results obtained in these studies are consistent with previously reports on the pharmacological activities of $O$. gratissimum [31], M. indica bark and leaf [32, 33], C. papaya [34] and P. guajava [35]. These findings lend pharmacological support to the reported folkloric uses of Nefang in the treatment of malaria and the role played by each of them.

\section{Conclusion}

The results obtained suggest that the constituent plants possess biologically active compounds with antipyretic, anti-inflammatory and antinociceptive activities. These findings define the role of each constituent plant, suggesting that these pharmacological activities are essential in the symptomatic management of malaria fever. These also provide scientific evidence that the therapeutic effects of Nefang are as a result of the synergy between antiplasmodial and other pharmacological activities of its constituent plants, thereby justify the folk use of Nefang for the treatment malaria fever. This could be useful in its subsequent development for clinical application.

\section{Competing interests}

The authors declare that they have no competing interests.

\section{Authors' contributions}

Conceived and designed the experiments: PAT FAO GAA ANG. Performed the experiments: PAT FAO JDS WNN AMM MJ. Analyzed the data: PAT FAO ANG. Reagent support: FAO ANG. Drafted the manuscript: PAT. All authors read and approved the final draft of the manuscript.

\section{Acknowledgement}

We gratefully acknowledge the technical assistance of Muchai PK (animal house attendant), Department of Pharmacology and Pharmacognosy, School of Pharmacy, University of Nairobi, Kenya.

\section{Author details}

${ }^{1}$ Centre for Research on Medicinal Plants and Traditional Medicine, Institute of Medical Research and Medicinal Plants Studies (IMPM), P. O. Box 6163, Yaoundé, Cameroon. '2Department of Pharmacology and Pharmacognosy, School of Pharmacy, University of Nairobi, P. O. Box 19676-00202, Nairobi, Kenya. ${ }^{3}$ Department of Veterinary Anatomy and Physiology, Faculty of Veterinary Medicine, University of Nairobi, P. O. Box 30197-00100, Nairobi, Kenya.

Received: 14 November 2014 Accepted: 29 May 2015

Published online: 09 June 2015

\section{References}

1. Snow RW, Marsh K. Malaria in Africa: progress and prospects in the decade since the Abuja Declaration. Lancet. 2010;376:137-9.

2. WHO. World Malaria Report 2013. World Health Organization, Geneva. http://www.who.int/malaria/publications/world_malaria_report_2013/en/.

3. Emergency response to artemisinin in the greater Mekong sub-region: regional framework for action 2013-2015. WHO 2013. http://www.who.int/ malaria Resistance in GMS Summary Report.

4. World Health Organization. Traditional medicine. Fact sheet No. 134. 2003. http://www.who.int/mediacentre/factsheets/2003/fs134/en/

5. Oliveira AB, Dolabela MF, Braga FC, Jacome RL, Varotti FP, Povoa MM. Plantderived antimalarial agents: new leads and efficient phythomedicines. Part I. Alkaloids. An Acad Bras Cienc. 2009:81:715-40.

6. Castellanos JRG, Prieto JM, Heinrich M. Red Lapacho (Tabebuia impetiginosa) - a global ethnopharmacological commodity? J Ethnopharmacol. 2009;121:1-13.

7. Ginsburg H, Deharo E. A call for using natural compounds in the development of new antimalarial treatments - an introduction. Malar J. 2011;10 Suppl 1:S1

8. Tarkang PA, Okalebo FA, Agbor GA, Tsabang N, Guantai AN, Rukunga GM. Indigenous knowledge and folk use of a polyherbal antimalarial by the Bayang community, South West Region of Cameroon. J Nat Prod Plant Res. 2012;2(3):372-80.

9. Tarkang PA, Atchan APN, Kuiate J, Okalebo FA, Guantai AN, Agbor GA Antioxidant potential of a polyherbal antimalarial as an indicator of its therapeutic value. Adv Pharmacol Sci. 2013;2013:678458.

10. Tarkang PA, Franzoi KD, Lee $S$, Lee $E$, Vivarelli $D$, Freitas-Junior $L$, et al. In vitro antiplasmodial activities and synergistic combinations of differential solvent extracts of the polyherbal product. Nefang BioMed Res Int. 2014;2014:835013.

11. Tarkang PA, Okalebo FA, Ayong LS, Agbor GA, Guantai AN. Anti-malarial activity of a polyherbal product (Nefang) during early and established Plasmodium infection in rodent models. Malar J. 2014:13:456.

12. Mbagwu HO, Anene RA, Adeyemi OO. Analgesic, antipyretic and anti-inflammatory properties of Mezoneuron benthamianum Baill Caesalpiniaceae. Niger Quart J Hosp Med. 2007;17(1):35-41.

13. Turner RA. Screening method in Pharmacology. New York \& London: Academic; 1965. p. 268.

14. Mohamed-Saleem TK, Azeem AK, Dilip C, Sankarl C, Prasanth NV, Duraisami R. Anti-inflammatory activity of the leaf extracts of Gendarussa vulgaris Nees. Asian Pac J. Trop Biomed 2011, 1(2):147-149.

15. Randall LO, Selitto JJ. A method for measurement of analgesic activity on inflamed tissue. Arch Int Pharmacodyn. 1957;111:409-19.

16. Kitchen I. Modification of an analgesy meter for paw pressure antinociceptive testing in neonatal rats. J Pharmacol Meth. 1984;12:255-8.

17. Ramesh R. Analgesic Effects of the aqueous extracts of plant Ipomea pes-tigridis studied in albino mice. Global J Pharmacol. 2010;4(1):31-5. 
18. Janssen PAJ, Jagenea AH. A new series of potent analgesics: Dextro 2,2diphenyl-3 methyl- hmorholino- butryprolidine and related amides. Part 1. Chemical structure and pharmacological activity. J Pharm. 1957;9:38.

19. Gupta M, Mazumder UK, Kumar RS, Gomathi P, Rajeshwar Y, Kakoti BB, et al. Anti-inflammatory, analgesic and antipyretic effects of methanol extract from Bauhinia racemosa stem bark in animal models. J Ethnopharmacol. 2005;98(3):267-73.

20. Okokon JE, Nwafor PA, Abia GO, Bankhede HK. Antipyretic and antimalarial activities of crude leaf extract and fractions of Enicostema littorale. Asian Pac J Trop Dis. 2012;2(6):442-7.

21. Al-Ghamdi MS. The anti-inflammatory, analgesic and antipyretic activity of Nigella sativa. J Ethnopharmacol. 2001;76:45-8.

22. Westfall TC, Westfall DP, Adrenergic agonists and antagonists. In: Brunton LL, Chabner BA, Knollman BC, editors. Goodman and Gilman's the pharmacological basis of therapeutics. 12th ed. New York, USA: McGraw-Hill Companies; 2011. p. 277-334.

23. Chandrasekharan NV. COX-3, a cyclooxygenase-1 variant inhibited by acetaminophen and other analgesic/antipyretic drugs: cloning, structure and expression. Proceedings National Acad Sci. 2002;99:13926-31.

24. Rang HP, Dale MM, Ritter JM, Moore PK. Pharmacology. 6th ed. Edinburgh: Churchill Livingstone; 2007. p. 557-87.

25. Crunkhon $P$, Meacock SER. Mediators of the inflammation induced in the rat paw by carrageenan. Brit J Pharmacol. 1971;42:392-402.

26. Georgewill OA, Georgewill UO. Evaluation of the anti-inflammatory activity of extract of Vernonia Amygdalina. Asian Pac J Trop Med. 2010;3(2):150-1.

27. Chindo BA, Amos S, Odutola AA, Vongtau HO, Abah J, Wambebe C, et a. Central nervous system activity of the methanolic extract of Ficus platyphylla stem bark. J Ethnopharmacol. 2003:85:131-7.

28. Vongtau HO, Abbah J, Mosugu O, Chindo BA, Ngazal IE, Salawu AO, et al. Antinociceptive profile of the methanolic extract of Neorautanenia mitis root in rats and mice. J Ethnopharmacol. 2004;92(2 \& 3):317-24.

29. Tjølsen $\mathrm{A}$, Berge $\mathrm{O}$, Hunskaar $\mathrm{S}$, Rosland $\mathrm{JH}$, Hole K. The formalin test; an evaluation of the method. Pain. 1992;51:5-17.

30. Eaton DC, Pooler JP. Vander's Physiology. 7th ed. USA: McGraw-Hill Lange; 2009. p. 230

31. Gege-Adebayo GI, Bassi AS, Igbokwe VU, Shafe MO. Antipyretic effect of Ocimum gratissium on brewer's yeast induced fever in wistar rats. J Medicine Medical Sc. 2013;4(6):247-51.

32. Ojewole JA. Anti-inflammatory, analgesic and hypoglycemic effects of Mangifera indica Linn. (Anacardiaceae) stem-bark aqueous extract. Methods Find Exp Clin Pharmacol. 2005;27(8):547-54.

33. Olorunfemi OJ, Nworah DC, Egwurugwu JN, Hart VO. Evaluation of antiinflammatory, analgesic and antipyretic effect of Mangifera indica leaf extract on fever-induced albino rats (wistar). British J Pharmacol Toxicol. 2012:3(2):54-7.

34. Sagnia B, Fedeli D, Casetti R, Montesano C, Falcioni G, Colizzi V. Antioxidant and anti-Inflammatory activities of extracts from Cassia alata, Eleusine indica, Eremomastax speciosa, Carica papaya and Polyscias fulva medicinal plants collected in Cameroon. PLoS One. 2014:9(8):e103999.

35. Ojewole JAO. Anti-inflammatory and analgesic effects of Psidium guajava Linn. (Myrtaceae) leaf aqueous extracts in rats and mice. Methods Find Exp Clin Pharmacol. 2006;28(7):441-6.

\section{Submit your next manuscript to BioMed Central and take full advantage of:}

- Convenient online submission

- Thorough peer review

- No space constraints or color figure charges

- Immediate publication on acceptance

- Inclusion in PubMed, CAS, Scopus and Google Scholar

- Research which is freely available for redistribution 